\title{
Acute Parotitis: A Rare Complication of Fine Needle Aspiration in Warthin Tumour
}

Margarida Viana Coelho, Domingos Sousa, Sergio Antunes da Silva, Rui Marques Osorio, Rita Martins Fernandes, Ana Isabel Rodrigues Internal Medicine Department, Hospital de Faro, Centro Hospitalar Universitário do Algarve, Faro, Portugal

Received: 07/05/2019

Accepted: $16 / 05 / 2019$

Published: 14/06/2019

How to cite this article: Viana Coelho M, Sousa D, Antunes da Silva S, Marques Osorio R, Martins Fernandes R, Rodrigues Al. Acute parotitis: a rare complication of fine needle aspiration in warthin tumour. EJCRIM 2019;6: doi:10.12890/2019_001147.

Conflicts of Interests: The Authors declare that there are no competing interests.

This article is licensed under a Commons Attribution Non-Commercial 4.0 License

\section{ABSTRACT}

Salivary gland tumours are a group of neoplasms with considerable heterogeneity regarding their histology and biological behaviour. Warthin tumour (WT) is the second most common benign parotid tumour. Options for tissue diagnosis include fine needle aspiration (FNA) and ultrasound-guided core needle biopsy. Complications related to FNA are rare. We present the case of a 49-year-old man admitted with parotitis after FNA and discuss management and an alternative investigative approach when WT is strongly suspected.

\section{LEARNING POINTS}

- Warthin tumour (WT) can be clinically suspected based on location (parotid gland tail), cystic texture, patient sex (male) and age (fifth and sixth decades of life), after exclusion of features related to malignancy.

- Complications of fine-needle aspiration (FNA) for WT diagnosis are rare and most commonly include haemorrhage, facial nerve injury, cellulitis at the needle puncture site and, less frequently, parotitis.

- When diagnosing tumours strongly suspected of being WT, the clinician should avoid routine FNA and instead use combined imaging studies.

\section{KEYWORDS}

Fine-needle aspiration, Warthin tumour, parotitis

\section{INTRODUCTION}

Salivary gland disease is usually classified into three groups: infectious, inflammatory or neoplastic. When neoplastic causes are being considered, tissue diagnosis is required to determine whether the tumour is benign or malignant. Gold standard options include fine needle aspiration (FNA) and ultrasound-guided core needle biopsy.

Some authors consider Warthin tumour (WT) to be a specific histological entity as it consists of epithelial cells (transformed into oncocytes), myoepithelial cells and a dense lymphoid infiltrate ${ }^{[1,2]}$. Patients typically present with painless parotid swelling usually located in the tail of the parotid gland, with palpation showing a cystic texture. WT occurs more commonly in the fifth and sixth decades of life, with a recognized male predilection.

Complications following FNA in this setting are rare, but haemorrhage, facial nerve injury, cellulitis at the puncture site and, less frequently, parotitis can occur. 


\section{CASE DESCRIPTION}

A 49-year-old man was admitted to our internal medicine department with complaints of acute swelling and severe tenderness of the parotid gland accompanied by skin hyperaemia, which had started 1 day after FNA. His temperature was above $38.2^{\circ} \mathrm{C}$. There was no exudation of pus. Apart from the FNA procedure, there were no other predisposing factors for hot/tender parotitis, such as trauma, stones in Stensen's duct, dehydration, poor oral hygiene or previous surgery. Since acute parotitis is most commonly due to Staphylococcus aureus and mixed oral aerobes and/or anaerobes, the patient was treated with intravenous antibiotics (amoxicillin-clavulanate and clindamycin) for 10 days and then continued with oral antibiotics for an additional 2 weeks. The parotitis completely resolved. The final diagnosis was WT (Fig. 1).

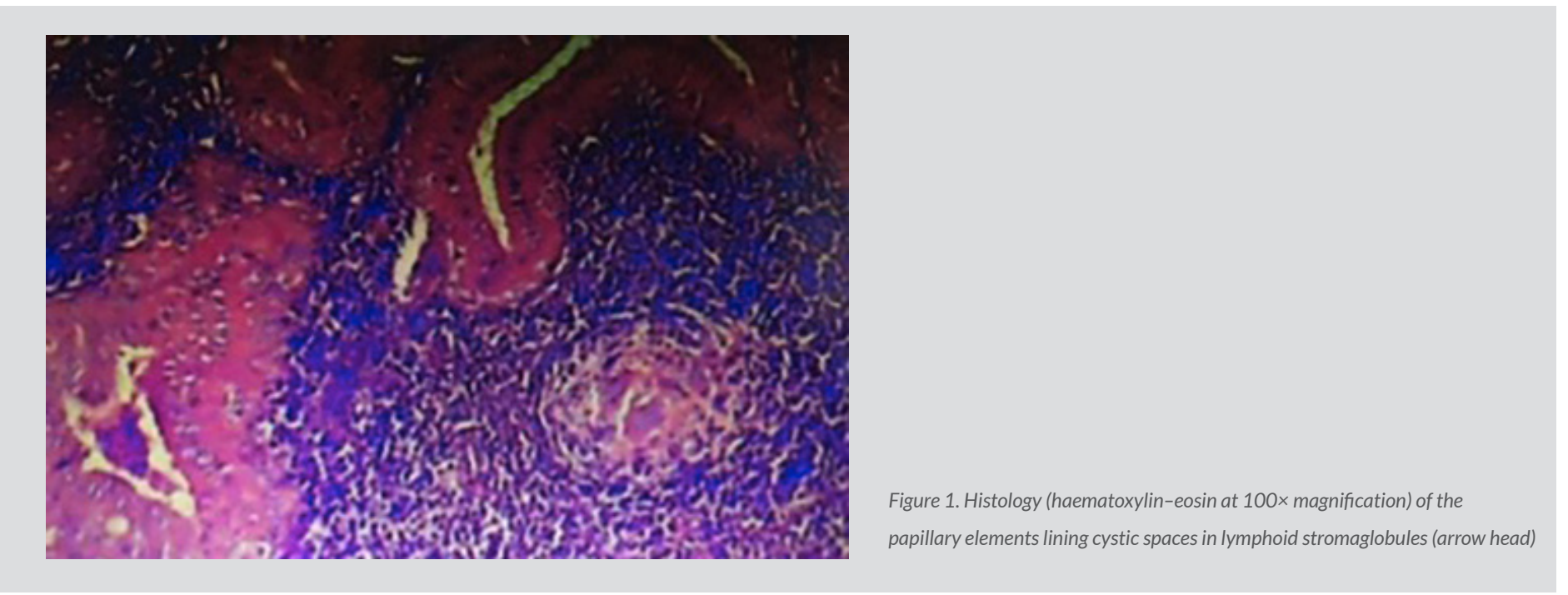

\section{DISCUSSION}

Complications following FNA are infrequent, and reports in the literature are sparse ${ }^{[1-4]}$. Some authors suggest that the inflammatory process in WT is due to its histology combined with a poor blood supply, making it susceptible to inflammation and infarction ${ }^{[1,2,4,5]}$. As in the present case, reports in the literature consider FNA to be a traumatic event which increases the risk for clinical parotitis.

Although the gold standard for the tissue diagnosis of parotid tumours is biopsy, many authors suggest that in the setting of a strong suspicion of WT (after exclusion of malignancy based on patient history, symptoms and physical examination), the clinician approach diagnosis with combined imaging modalities such as computed tomography $(\mathrm{CT})$ and magnetic resonance $(\mathrm{MR})^{[6,7]}$, in order to avoid unnecessary biopsy, thus avoiding risks related to the procedure.

As WT is benign with an extremely low incidence of malignant transformation, some authors advocate conservative management with follow-up imaging. CT and MRI help to differentiate intra- and extraglandular locations and detect local invasion and nodal and systemic metastases. In this approach, both parotid glands should be evaluated since WT can be multifocal and bilateral, which is rare in malignant histological tumour types.

\section{REFERENCES}

1. Bahar G, Dudkiewicz M, Feinmesser R, Joshua BZ, Braslavsky D, Popovtzer A, et al. Acute parotitis as a complication of fine-needle aspiration in Warthin's tumor: a unique finding of a 3-year experience with parotid tumor aspiration. Otolaryngol Head Neck Surg 2006;134:646-649.

2. Suzuki K, Iwai H, Kaneko T, Sakaguchi M, Hoshino S, Inaba M, et al. Induction of parotitis by fine-needle aspiration in parotid Warthin's tumor. Otolaryngol Head Neck Surg 2009;141:282-284.

3. Gavín-Clavero MA, Usón-Bouthelier T, Jariod-Ferrer UM, Fernández-Larrañaga A, Pantilie B, Lobera-Molina F, et al. Precisión de la PAAF (punción aspiración con aguja fina) y la TAC (tomografía axial computerizada) en la diferenciación de tumores benignos y malignos de parótida en una serie de casos. Acta Otorrinolaringol Esp 2017:69(1):25-29.

4. Eveson JW, Cawson RA. Infarcted ("infected”) adenolymphomas. A clinicopathological study of 20 cases. Clin Otolaryngol 1989;14:205-210.

5. Di Palma S, Simpson RH, Skalova A, et al. Metaplastic (infarcted) Warthin's tumour of the parotid gland: a possible consequence of fine needle aspiration biopsy. Histopathology 1999;35:432-438.

6. Alibek S, Zenk J, Bozzato A, Lell M, Grunewald M, Anders K, Greess H. The value of dynamic MRI studies in parotid tumors. Acad Radiol 2007;14(6):701-710.

7. Kinoshita T, Ishii K, Naganuma H. MR imaging findings of parotid tumors with pathologic diagnostic clues. A pictorial essay. Clin Imaging 2004;28:93-101. 
European Journal

of Case Reports in

Internal Medicine 